\title{
Cost Analysis of an Ammonia Dry Cooling System with a Chicago Bridge \& Iron Peak Shaving System
}

M. K. Drost

B. M. Johnson

December 1980

Prepared for the U.S. Department of Energy under Contract DE-AC06-76RLO 1830

Pacific Northwest Laboratory Operated for the U.S. Department of Energy by Battelle Memorial Institute 
NOTICE

This report was prepared as an account of work sponsored by the United States Government. Neither the United States nor the Department of Energy, nor any of their employees, nor any of their contractors, subcontractors, or their employees, makes any warranty, express or implied, or assumes any legal liability or responsibility for the accuracy, completeness or usefulness of any information, apparatus, product or process disclosed, or represents that its use would not infringe privately owned rights.

The views, opinions and conclusions contained in this report are those of the contractor and do not necessarily represent those of the United States Government or the United States Department of Energy.

\author{
PACIFIC NORTHWEST LABORATORY \\ operated by \\ BATTELLE \\ for the \\ UNITED STATES DEPARTMENT OF ENERGY \\ Under Contract DE-AC06-76RLO 1830
}

\author{
Printed in the United States of America \\ Available from \\ National Technical Information Service \\ United States Department of Commerce \\ 5285 Port Royal Road \\ Springfield, Virginia 22151
}

Price: Printed Copy s

$\because$ Microfiche $\$ 3.00$

NTIS

-Pages Selling Price

$\begin{array}{ll}001-025 & \$ 4.00 \\ 026-050 & \$ 4.50 \\ 051-075 & \$ 5.25 \\ 076-100 & \$ 6.00 \\ 101-125 & \$ 6.50 \\ 126-150 & \$ 7.25 \\ 151-175 & \$ 8.00 \\ 176-200 & \$ 9.00 \\ 201-225 & \$ 9.25 \\ 226-250 & \$ 9.50 \\ 251-275 & \$ 10.75 \\ 276-300 & \$ 11.00\end{array}$




\title{
33679000544777
}

\author{
INTERIM REPORT \\ COST ANALYSIS OF AN AMMONIA DRY \\ COOLING SYSTEM WITH A CHICAGO \\ BRIDGE \& IRON PEAK SHAVING SYSTEM
}

M. K. Drost

B. M. Johnson

December 1980

Prepared for the U.S. Department of Energy under Contract DE-AC06-76RLO-1830

Pacific Northwest Laboratory Richland, Washington 99352 



\section{FOREWORD}

The Dry Cooling Enhancement Program at Pacific Northwest Laboratory (PNL) was initiated with a program scope that included the following near-term and ultimate emphasis.

Near-Term Objectives:

Develop economic and performance models for cost optimization of total heat rejection systems using dry and dry/wet cooling.

Analyze and disseminate operating experience on existing dry-cooled plant performance.

Demonstrate certain features of existing technology equipment to provide confidence for specification by utilities.

Ultimate Objective:

Promote water conservation through industry use of dry cooling by developing and demonstrating the reliability of lower cost systems. The development of advanced dry/wet systems is also considered to be within this scope.

The following documents have been issued, reporting the results of the work toward these objectives.

Cost optimization of dry-cooled heat rejection systems:

\footnotetext{
A REVIEW AND ASSESSMENT OF ENGINEERING ECONOMIC STUDIES OF DRY-COOLED ELECTRICAL GENERATING PLANTS. B. C . Fryer, BNWL-1976, March 1976.

HEAT TRANSFER AND PRESSURE DROP CHARACTERISTICS OF DRY TOWER EXTENDED SURFACES. PART I: HEAT TRANSFER AND PRESSURE DROP DATA. PFR Engineering Systems, Inc., PFR 7-100, March 1976.

HEAT TRANSFER AND PRESSURE DROP CHARACTERISTICS OF DRY TOWER EXTENDED SURFACES. PART II: DATA ANALYSIS AND CORRELATION. PFR Engineering Systems, Inc., PFR 7-102, June 1976.
} 
Analysis of performance of existing dry-cooled plants:

DRY COOLING TOWER PROGRAM: RESULTS OF INDUSTRIAL CONTACTS THROUGH AUGUST 1974. BNWL-1878, November 1, 1974.

A SURVEY OF MATERIALS AND CORROSION PERFORMANCE IN DRY COOLING APPLICATIONS. A. B. Johnson, Jr., D. R. Pratt and G. E. Zima, BNWL-1958, March 1976.

EUROPEAN DRY COOLING TOWER OPERATING EXPERIENCE.

J. G. DeSteese and K. Simhan, BNWL-1955, March 1976.

MATHEMATICAL AND EXPERIMENTAL INVESTIGATIONS ON DISPERSION AND RECIRCULATION OF PLUMES FROM DRY COOLING TOWERS AT WYODAK POWER PLANT IN WYOMING. Y. Onishi and D. S. Trent, BNWL-1982, February 1976.

ALUMINUM ALLOY PERFORMANCE UNDER DRY COOLING TOWER CONDITIONS. A. B. Johnson, Jr., S. Begaj, M. W. Martini, and R. P. May, PNL-2392, December 1977.

Advanced dry (dry/wet)-cooled systems :

PRELIMINARY EVALUATION OF WET-DRY COOLING CONCEPTS FOR POWER PLANTS. W. B. Loscutoff, BNWL-1969.

COMPATIBILITY OF AMMONIA WITH CANDIDATE DRY COOLING SYSTEM MATERIALS. D. R. Pratt, BNWL-1991, Apri1 1976.

SCALE FORMATION IN DELUGED DRY COOLING SYSTEMS.

D. R. Pratt, BNWL-2060, March 1976.

AMMONIA AS AN INTERMEDIATE HEAT EXCHANGE FLUID DRY FOR DRYCOOLED TOWERS. R. T. Allemann, B. M. Johnson, and G. C. Smith, BNWL-SA-5997, September 1976.

AUGMENTED DRY COOLING SURFACE TEST PROGRAM: ANALYSIS AND EXPERIMENTAL RESULTS. H. L. Parry et a1. PNL-2746, September 1979 .

A group of reports (including this report) has been isued that serves the dual purpose of: 1) developing cost optimization models for dry cooling systems based on available technology and 2) comparing the results of analyzing the cost of these systems with the projected cost of several advanced dry and dry/wet systems. Included in this group are: 
AN ENGINEERING AND COST COMPARISON OF THREE DIFFERENT ALL-DRY COOLING SYSTEMS. B. C. Fryer, D. W. Faletti, Daniel J. Braun, David J. Braun and L. E. Wiles, BNWL-2121, September 1976.

A STUDY OF THE COMPARATIVE COSTS OF FIVE WET/DRY COOLING TOWER CONCEPTS. F. R. Zaloudek, R. T. Allemann, D. W. Faletti, B. M. Johnson, H. L. Parry, G. C. Smith, R. D. Tokarz, and R. A. Walter, BNWL-2122, September 1976.

DRY COOLING OF POWER GENERATING STATIONS: A SUMMARY OF THE ECONOMIC EVALUATION OF SEVERAL ADVANCED CONCEPTS VIA A DESIGN OPTIMIZATION STUDY AND A CONCEPTUAL DESIGN AND COST ESTIMATE. B. M. Johnson, R. T. Allemann, D. W. Faletti, B. C. Fryer and F. R. Zaloudek, BNWL-2120, September 1976.

COSTS AND COST ALGORITHMS FOR DRY COOL ING TOWER SYSTEMS. P. A. Ard, C. H. Henager, D. R. Pratt and L. E. Wiles, BNWL-2123, September 1976.

A USER'S MANUAL FOR THE BNW-I OPTIMIZATION CODE FOR DRY-COOLED POWER PLANTS. David J. Braun, Daniel J. Braun, Warren V. DeMier, D.W. Faletti and L. E. Wiles, BNWL-2180, January 1977.

COMPARATIVE COST STUDY OF FOUR WET/DRY COOLING CONCEPTS THAT USE AMMONIA AS THE INTERMEDIATE HEAT EXCHANGE FLUID. R. D. Tokarz, Daniel J. Braun, B. M. Johnson, R. T. Allemann, David J. Braun, H. L. Parry, G. C. Smith and F. R. Zaloudek, PNL-2661, September 1978.

AN ENGINEERING AND COST ANALYSIS OF A DRY COOLING SYSTEM AUGMENTED WITH A THERMAL STORAGE POND. M. K. Dorst and R. T. Allemann, PNL-2745, September 1978.

A USER'S MANUAL FOR THE BNW-II OPTIMIZATION CODE FOR DRY/WET-COOLED POWER PLANTS. Daniel J. Braun, Judith A. Bamberger, David J. Braun, Duane W. Faletti, Lawrence E. Wiles, PNL-2674, Vol. I, May 1978.

A DESCRIPTION AND COST ANALYSIS OF A DELUGE DRY/WET COOLING SYSTEM. L. E. Wiles et al. PNL-2498, June 1978.

Four reports have been issued which consider the future need for any cooling and the potential benefit/cost ratio of a large-scale demonstration. 
AN OVERVIEW OF ECONOMIC, LEGAL, AND WATER AVAILABILITY FACTORS AFFECTING THE DEMAND FOR DRY AND WET/DRY COOLING OF THERMAL POWER PLANTS. P. L. Hendrickson, BNWL-2268, June 1977.

AN OVERVIEW OF ECONOMIC, LEGAL, AND WATER AVAILABILITY FACTORS AFFECTING THE DEMAND FOR DRY AND WET/DRY COOLING OF THERMAL POWER PLANTS. P. L. Hendrickson, BNWL-2268, September 1978.

ESTIMATION OF BENEFITS FROM DEMONSTRATING ADVANCED DRY COOLING TECHNOLOGY: A FRAMEWORK AND PARTIAL ANALYSIS.

J. W. Currie and T. J. Foley, BNWL-2182, Apri1 1977.

POTENTIAL USE OF DRY COOLING IN SUPPORT OF ADVANCED ENERGY GENERATION SYSTEMS. D. W. Mayer, E. M. Arnold, and R. T. Allemann, PNL-3149, September 1979. 


\section{ACKNOWLEDGEMENTS}

This report contains an account of the work sponsored by the Division of Advanced Systems and Materials Production of the U.S. Department of Energy (DOE) under the Dry Cooling Enhancement Program at the Pacific Northwest Laboratory (PNL). This work was completed under the direction of I. Helms and W. F. Savage, Project Officer and Manager, respectively, Advanced Concepts Evaluation Section of the Advanced Nuclear Systems and Projects Division; and B. M. Johnson, Manager of the Dry Cooling Enhancement Program at PNL. Assistance was provided by B. Y. Lai and M. Husain of Chicago Bridge and Iron Company. P. Goodenough, PNL word processor, provided typing production support. 
,

(⿸丆口 


\section{CONTENTS}

FOREWORD

ACKNOWLEDGMENTS

i i i

vi $i$

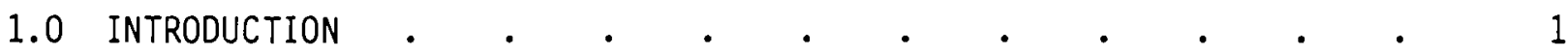

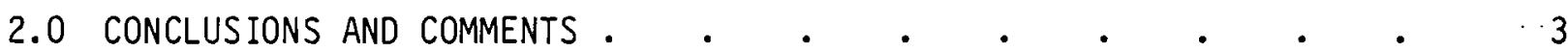

3.0 BACKGROUND $\quad . \quad$. $\quad . \quad . \quad . \quad . \quad . \quad . \quad . \quad . \quad 5$

3.1 INCENTIVES FOR ENHANCED DRY COOLING SYSTEMS $\quad . \quad$ • $\quad$ • 5

3.2 DOE/PNL DRY COOLING ENHANCEMENT PROGRAM • . $\quad . \quad$. 5

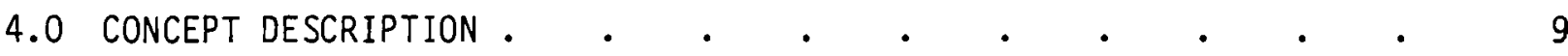

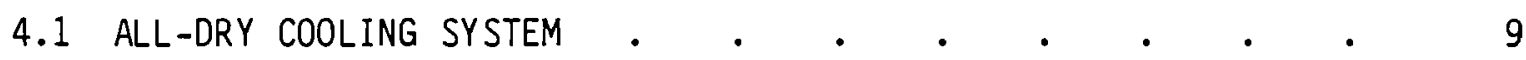

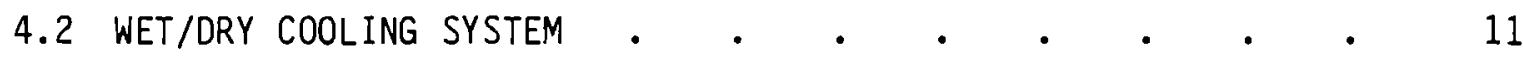

4.3 CHICAGO BRIDGE \& IRON CAPACITIVE SYSTEM • . . . . . $\quad 11$

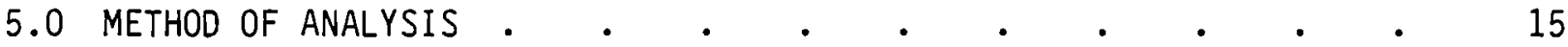

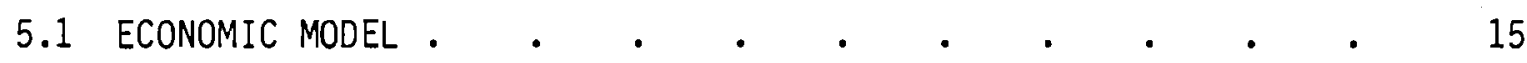

5.1.1 Cooling System Capital Cost . . . . . . . . 16

5.1.2 Capacitive System Capital Cost . . . . . . 16

5.1.3 Base Plant Scaling Capital Cost . . . . . 17

5.1.4 Replacement Capacity Capital Cost $\quad$. $\quad . \quad$. $\quad 17$

5.1.5 Annual Cost for Maintenance . . . . . . . 18

5.1.6 Annual Energy Cost to Replace Loss Câpacity . . 18

5.1.7 Annual Incremental Increase in Plant Fuel Cost . . 18

5.1.8 Annual Credit for Excess Generation . . . . 18

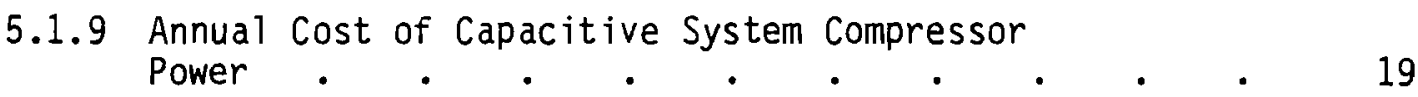

5.1.10 Annual Cost for Cooling System Makeup Water. $\quad$ - $\quad 19$

5.2 WINTER PEAKING ECONOMIC MODEL • . . . . . . . . . 19 


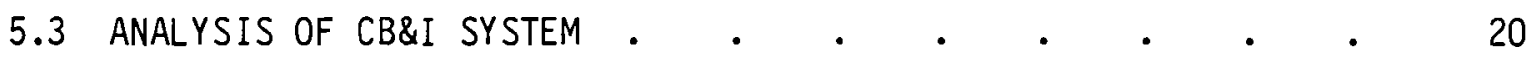

5.4 ANALYSIS OF DRY AND WET/DRY SYSTEMS $\quad . \quad \ldots \quad . \quad \ldots \quad . \quad$. $\quad . \quad 23$

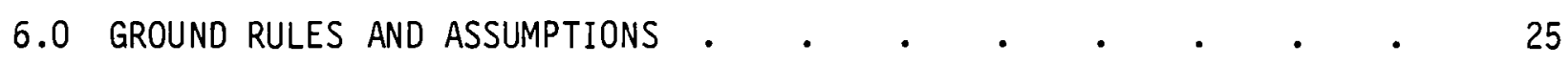

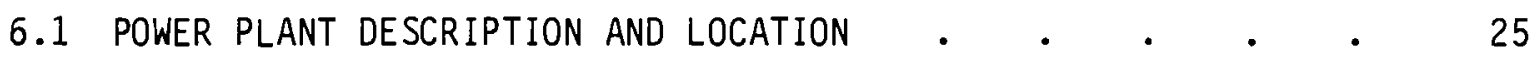

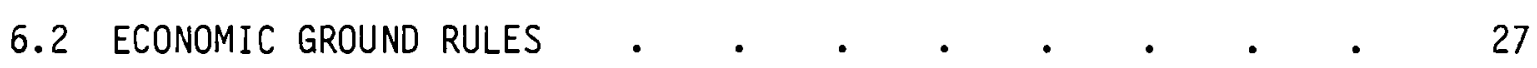

7.0 RESULTS

7.1 RESULTS OF SUMMER PEAKING UTILITY ANALYSIS $\quad . \quad$ • $\quad$ • $\quad$ • 29

7.2 RESULTS OF WINTER PEAKING UTILITY ANALYSIS $\quad . \quad$ • $\quad$ • $\quad 31$

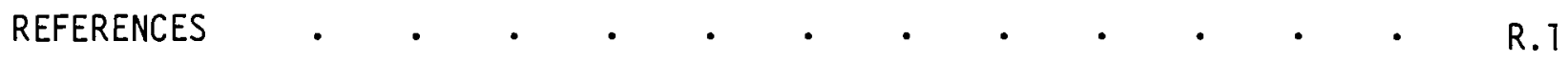

APPENDIX 650-MW FOSSIL PLANT EVALUATED ANNUAL PERFORMANCE WITH CHICAGO BRIDGE \& IRON

MECHANICAL DRAFT COOLING TOWER SYSTEM $• \quad \cdot \quad \cdot \quad \cdot \quad \cdot \quad$ A.T 


\section{FIGURES}

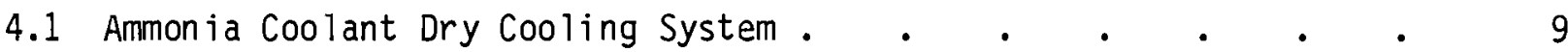

4.2 Temperature Relationship for Ammonia Coolant Dry

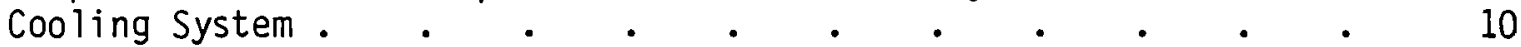

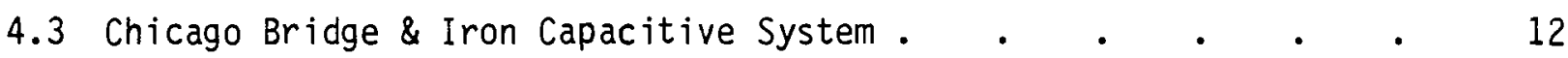

7.1 Incremental Cost as a Function of Water Consumption . . . 31

\section{TABLES}

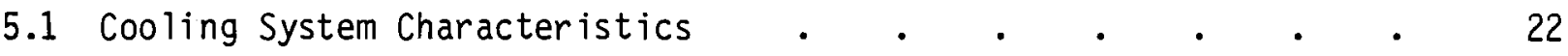

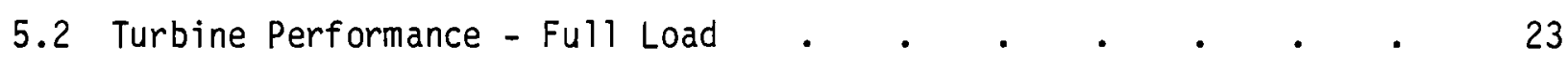

6.1 Annual Temperature Duration Data, Northeast Site . . . . 26

6.2 Modified Economic and Technical Design Conditions . . . . . 27

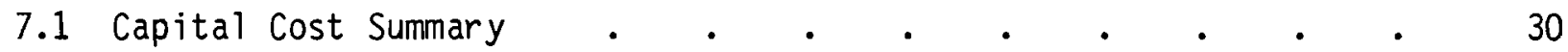

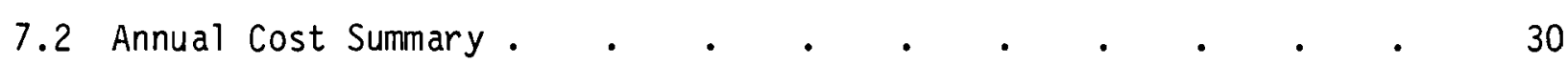

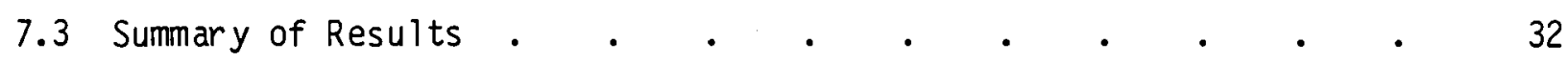

7.4 Capital Cost Summary - Winter Peaking Utility . . . . . 32

7.5 Annual Levelized Cost Summary - Winter Peaking Utility: Case I . 33

7.6 Annual Cost Summary - Winter Peaking Utility: Case II . . 33

A.1 650-MW Fossil Plant Evaluated Annual Performance • • • • A.1 

COST ANALYSIS OF AN AMMONIA DRY COOLING SYSTEM

WITH A CHICAGO BRIDGE \& IRON PEAK SHAVING SYSTEM

\subsection{INTRODUCTION}

The study described in this report was performed as part of the U.S. Department of Energy's Dry Cooling Enhancement Program at the Pacific Northwest Laboratory (PNL). The objective of the continuing study is to determine the potential for reducing the cost associated with dry cooling by using an ammonia dry cooling system augmented with the Chicago Bridge \& Iron peak shaving system.

This report documents the cost analysis of an all-dry ammonia cooling system operating in conjunction with a peak shaving system. The peak shaving system utilizes the excess cooling capability available at night to cool water to be used for supplemental cooling during the following day.

A particular arrangement of this system, described herein, has been proposed by Chicago Bridge \& Iron and will be referred to as the CB\&I system. A similar system for application with a conventional dry cooling system was proposed by Guyer (1) and reviewed by Drost. (2) Another concept using phased cooling has been proposed by Auburn University.

The analysis consisted of determining the incremental cost of cooling for the CB\&I system and comparing this cost to the incremental cost of cooling for both dry and wet/dry systems for a consistent set of design conditions and assumptions. The wet/dry systems were analyzed over a range of water usages. The design, performance and component capital costs for the capacitive system were provided by Chicago Bridge \& Iron and will only be summarized here. The dry and wet/dry systems were designed and costed by PNL using the BNW-I and BNW-I I computer codes. Components common to both the CB\&I and wet/dry systems were designed and costed by PNL to ensure consistency. 
The analysis was intended to be a first-order comparison of the CB\&I system with other proposed dry and dry/wet cooling schemes. An optimization of the CB\&I system was not attempted by CB\&I and several factors such as wet/dry tower maintenance and site sensitivity were not considered in detail.

The basis of the comparisons was a cooling system designed for installations with a 650-MWe (gross) coal-fired power plant. The plant was assumed to be located at Middletown, a hypothetical site near Boston, Massachusetts. The plant was assumed to be operated by utility with a summer peak that corresponded to the hottest time period. 


\subsection{CONCLUSIONS AND COMMENTS}

Based on the results of the study the following conclusions can be made.

1. The CB\&I system shows a substantial economic advantage when compared with an all-dry cooling system.

2. The CB\&I system appears to be competitive with wet/dry cooling systems using about 2 to $3 \%$ water. This implies that the CB\&I system can achieve the same results as a $97 \%$ dry/3\% cooperative (deluge) system without the potential problems associated with deluging. Systems using greater percentages of evaporative cooling do appear to be somewhat lower in cost than the CB\&I system.

3. The CB\&I system demonstrates a clear economic advantage when compared to both dry and wet/dry concepts for a winter peaking utility where the excess generation is assumed to displace both base-loaded coal-fired power generation and oil-fired gas turbine peaking units.

Other comments on the results of this study include:

1. The primary cost components are fixed charges on capital and credit for excess generation. This implies the need for a more detailed evaluation of the value of excess generation because the utility model used in this study was greatly simplified.

2. Maintenance costs and compression energy costs are not a substantial component of costs; therefore, the availability of off-peak power for compression energy is not a critical question. In addition, any reasonable increase in maintenance costs for the wet/dry system, to represent the increased maintenance due to deluging, would probably not change the results of the study.

3. More severe meteorology, such as hotter daytime temperatures and wider diurnal temperature difference, would probably increase the economic advantage of the CB\&I system when compared to the all-dry cooling 
system. No conclusions can be drawn about a comparison between the CB\&I system and wet/dry systems for more severe meteorology.

4. The results of the winter peaking utility analysis are dependent on utility-specific factors, particularly the demand curve. It is difficult to pick assumptions to accurately reflect all winter peaking utilities. 


\subsection{BACKGROUND}

The increased competition for existing water supplies has led to an increased interest in the use of dry cooling towers for steam power plant cooling. This is particularly important in the arid west and Southwest where water is sufficiently scarce that power plants with dry cooling towers have been built.

\subsection{INCENTIVES FOR ENHANCED DRY COOLING SYSTEMS}

The primary problem associated with the use of dry cooling towers for power plants is the severe economic penalties associated with the unavoidably higher heat rejection temperature in warm weather than with an equivalent wet

cooling tower. These higher temperatures for heat rejection not only increase the plant heat rate, making power more costly, but also may force a reduction in plant output on hot summer days when U.S. power demands are likely to be highest. This loss of capacity would have to be compensated for by the availability of excess capacities in the plant or in the utility's system, or through the purchase of power. The cost of this capability and the supplemental power are assessed against the dry cooling system.

Because of these economic penalties associated with dry cooling towers, there are strong incentives to develop systems that reduce the cost of using dry cooling towers. Several methods are currently being investigated at PNL. These include advanced dry cooling systems utilizing ammonia as a heat transfer fluid, and wet augmentation of dry systems. This study considers an alternative for improving dry cooling tower performance: adding capacitive storage of water as a periodic short-term heat sink to a dry cooling system with ammonia as an intermediate heat transfer fluid.

One problem inherent with an all-dry cooling system is that, in many utility systems, the maximum demand for heat rejection may occur during the hottest period of the day when a dry cooling tower's heat rejection capacity is the lowest. Conversely, the dry cooling tower has its greatest heat rejection capacity during the cool nights when the amount of rejected heat is 
significantly lower. A capacitive system can be used to balance the heat rejection load and the heat rejection capacity of a dry cooling system by storing the excess heat during the day for rejection at night.

Several capacitive systems have been proposed. A system consisting of a water storage pond for application with a conventional dry cooling system was

proposed by Guyer ${ }^{(1)}$ and analyzed by Drost. (2) A similar system for application with an ammonia dry cooling tower has been proposed by Chicago Bridge \& Iron Company. This system has the advantage of using the thermodynamic properties of ammonia to enhance of the dry cooling tower performance and $f a c i l i t a t e$ rejection of the stored excess heat.

The premise of a capacitive system is that it will reduce the cost of dry cooling by increasing the plant capacity during hot weather; thereby reducing the cost of replacement capacity and power. To meaningfully evaluate this premise, the incremental cost of an optimized ammonia dry cooling system combined with a capacitive system should be compared to the incremental cost of optimized dry or wet/dry cooling systems without a capacitive system. In this study Chicago Bridge \& Iron (CB\&I) designed the capacitive ammonia dry cooling system. Although this design was based on reasonable design conditions, the design was not optimized. The designs for the corresponding dry and wet/ dry ammonia cooling systems without capacitive cooling were developed using the BNW-I and BNW-II computer codes, which do produce an optimized design within the design constraints used for this study.

\subsection{DOE/PNL DRY COOLING ENHANCEMENT PROGRAM}

The objective of the U.S. Department of Energy/Pacific Northwest Laboratory (DOE/PNL) Dry Cooling Enhancement Program is to develop, demonstrate and disseminate to potential users, dry and wet/dry cooling tower technology, which can be applied to conserve scarce water resources, increase power plant siting flexibility and reduce degradation of power plant operation during yearly operation. 
As scoped, the Dry Cooling Enhancement (DCE) Program was divided into several areas:

- determination of the role of dry cooling in meeting national energy needs

- cooperative testing and evaluation of state-of-the-art dry and wet/dry cooling systems

- analysis and design assessment of new dry cooling ideas

- development of unique design features of advanced concepts

- demonstration of advanced concepts

This report describes work performed under the third task area. The objective of this task is to provide critical appraisals of new technology or design concepts. Continuing appraisals, similar to the one reported here, will be performed through analytic evaluation, design studies and economic evaluation to normalize and compare claims of costs and performance of competing concepts. The results of this task will be used to identify the most advantageous concepts for further development and demonstration under the last task. 



\subsection{CONCEPT DESCRIPTION}

In this study the CB\&I system was compared to an all-dry ammonia cooling system and a wet/dry ammonia cooling system to provide insight into the incentives for developing a capacitive cooling system vis-a-vis a wet/dry cooling system. Each concept will be briefly described.

\subsection{ALL-DRY COOLING SYSTEM}

The all-dry cooling system considered in this study is an ammonia system similar to that described by Faletti et al. (3). The system uses ammonia as the heat transport fluid and consists of three components: a condenser/ reboiler, piping and the cooling tower. This system is shown in Figure 4.1 . The temperature relationships are shown in Figure 4.2.

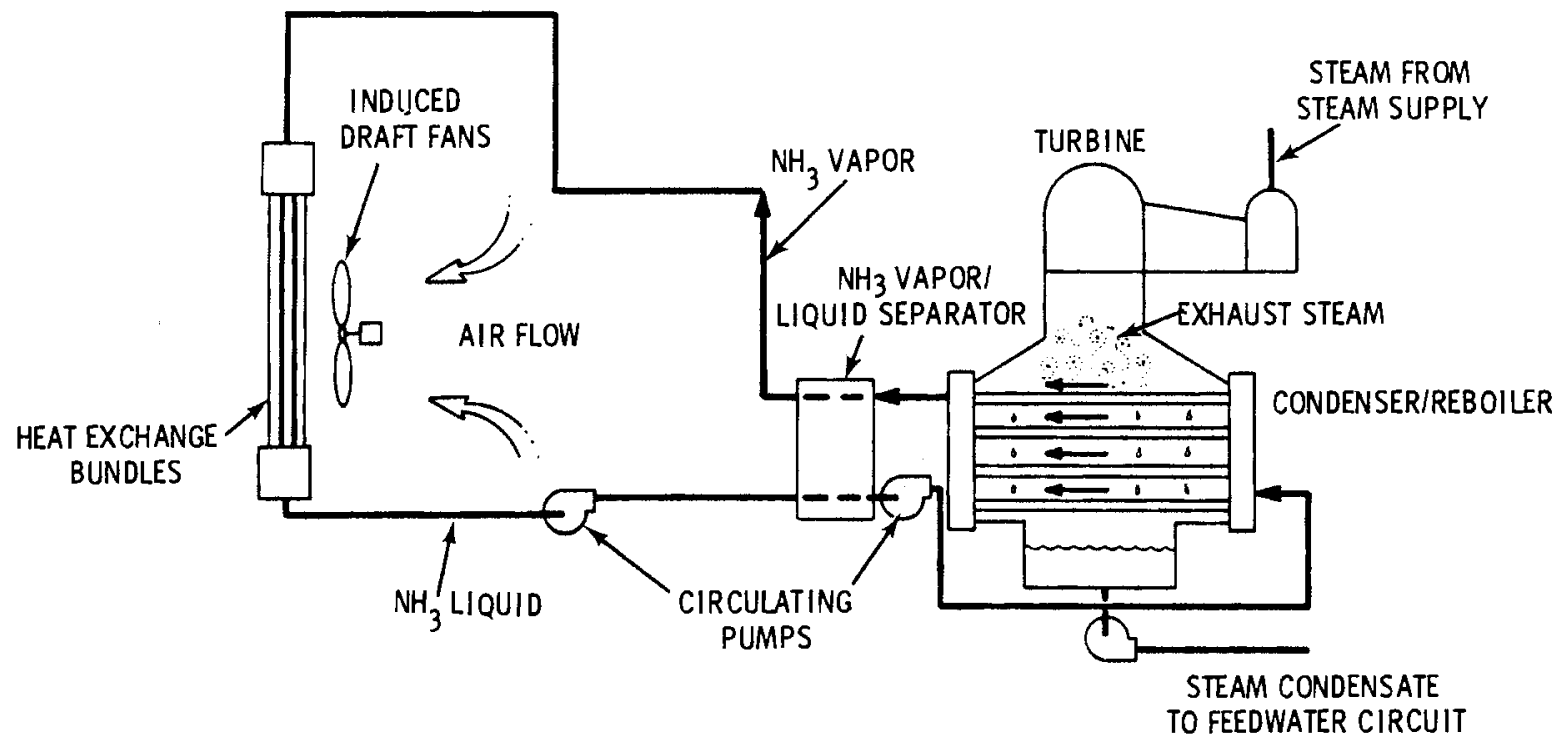

FIGURE 4.1. Ammonia Coolant Dry Cooling System 


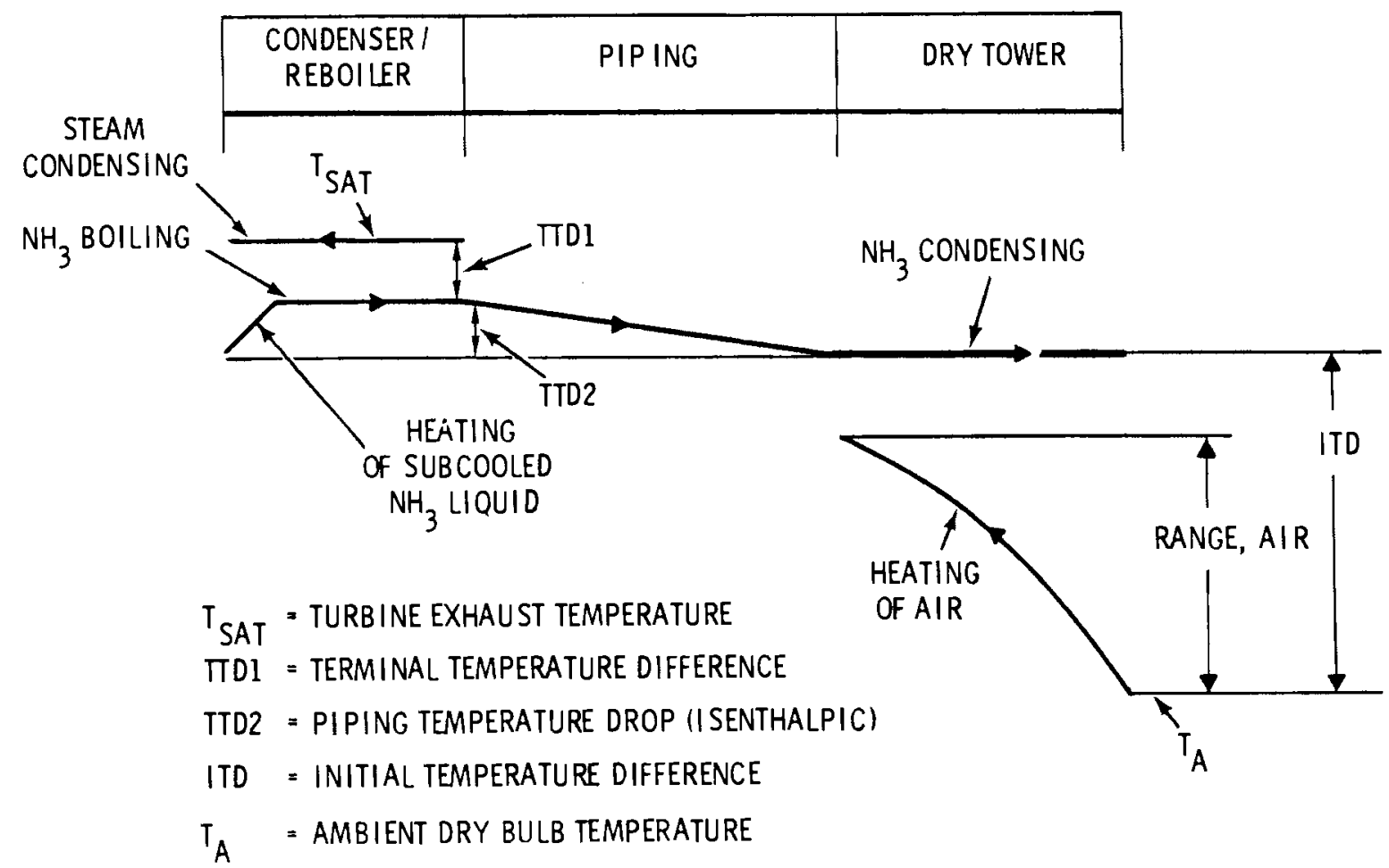

FIGURE 4.2. Temperature Relationships for Ammonia Coolant Dry Cooling System

The turbine exhaust steam is condensed at constant temperature on the outside of the condenser/reboiler tubes. Liquid ammonia passing through the tubes is boiled at constant temperature. The two-phase mixture is separated; the liquid is returned to the condenser/reboiler while the ammonia vapor is piped to the cooling tower. In the supply piping the ammonia vapor experiences a pressure drop, which results in a temperature drop. The vapor is condensed in the cooling tower and the liquid ammonia is returned to the condenser/ reboiler. The condenser/reboiler is similar to a conventional condenser except that the water boxes would be replaced with high pressure headers, and tubes with enhanced heat-transfer surfaces would be used to increase heat transfer between the condensing steam and boiling ammonia. 
The cooling tower of the all-dry system is similar to other dry tower designs except that ammonia is condensed in a vertical one-pass heat exchanger. Armonia vapor enters the top of the heat exchangers and condenses as it flows down the inside of the finned tubes.

\subsection{WET/DRY COOLING SYSTEM}

The wet/dry cooling system is similar to the all-dry system. The system configuration, condenser/reboiler and piping are the same for each concept. The cooling tower is different from that used in the all-dry system in two ways. First, the finned tube heat exchanger is arranged horizontally rather than vertically. Second, the cooling capacity of the finned surface can be enhanced by deluging the heat exchange surfaces with water. The water is distributed to the top of the plate fins. The water forms a film over the plate fins and is allowed to flow to the base of the tower where it is collected and recirculated. As water evaporates from the plate fins, additional heat is rejected and the cooling capacity is increased.

Deluging is utilized during periods of high dry-bulb temperature and tends to reduce the power plant capacity penalty caused by dry cooling. The amount of water available for deluging is determined by site characteristics.

\subsection{CHICAGO BRIDGE \& IRON COMPANY CAPACITIVE SYSTEM}

The CB\&I dry cooling system consists of an ammonia dry cooling system similar to that described in Section 4.1 and a capacitive system that stores excess heat generated during the hot periods of the day for rejection during cool periods of the day. The CB\&I dry cooling system is shown in Figure 4.3.

The ammonia dry cooling system consists of a condenser/reboiler, piping and the ammonia dry cooling tower. Turbine exhaust steam is condensed in the condenser/reboiler and the rejected heat is used to evaporate ammonia in the condenser/reboiler tubes. The ammonia vapor is piped to the cooling tower where the ammonia vapor is condensed and liquid ammonia is collected in the liquid ammonia receiver for return to the condenser/reboiler. 


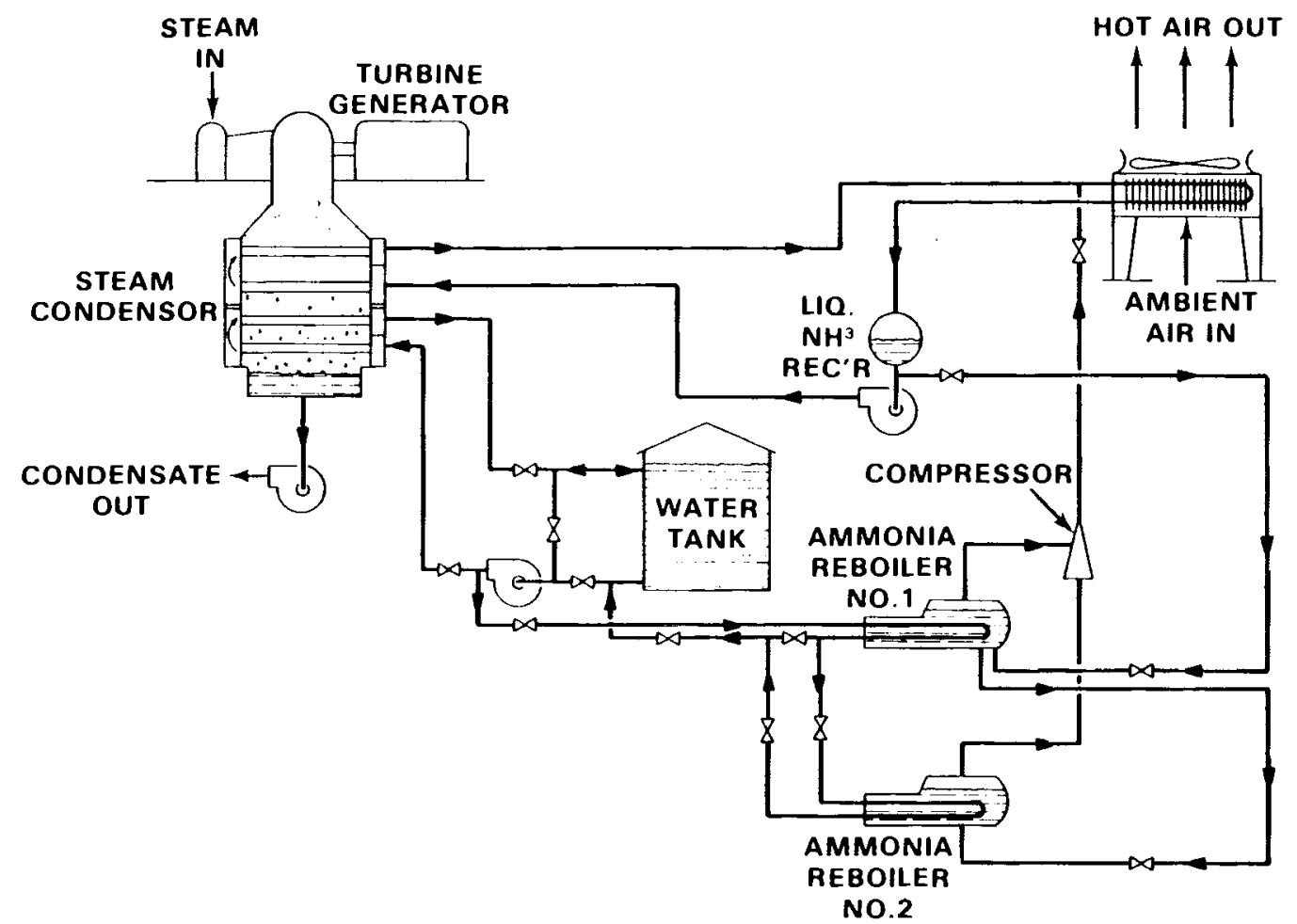

FIGURE 4.3. Chicago Bridge \& Iron Capacitive System 
The capacitive system stores thermal energy, which cannot be rejected from the cooling tower during the peak temperature period of the day. The heat is stored as sensible heat in water contained in a large storage tank. To accom$\mathrm{plish}$ the heat rejection to the water, the steam condenser is divided into an ammonia condenser/reboiler and a water-cooled condenser. When the ambient air temperature becomes too high to allow all the heat to be rejected through the ammonia dry cooling system, cool water from the storage tank is circulated through the water-cooled condenser, heated and returned to the storage tank. The hot water is returned to the top of the tank while cold water is removed from the bottom of the tank. This allows a thermocline to form, separating the hot and cold water.

During the cool part of the day, the hot water stored in the tank is cooled in two ammonia reboilers as shown in Figure 4.3. Liquid ammonia from the cooling tower liquid ammonia receiver is expanded to a lower pressure and temperature. In the ammonia reboiler, heat is removed from the storage water and used to vaporize a portion of the ammonia. The second ammonia reboiler operates in series with the first; the ammonia is expanded to a lower pressure in the second ammonia reboiler. The ammonia vapor from both reboilers is compressed and returned to the cooling tower where the heat is rejected to atmosphere. 


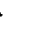

.

. 


\subsection{METHOD OF ANALYSIS}

The methodology used in this study involved the development of a consistent economic model that would allow the comparison of the CB\&I capacitive system with other proposed dry and wet/dry cooling systems. After the economic model was developed, the CB\&I capacitive system and alternate cooling systems were analyzed with respect to performance and economics.

\subsection{ECONOMIC MODEL}

The economic model used in this study is based on that used in the BNW-I and BNW-II computer codes $(4,5)$ but the model has been modified to include additional costs and credits associated with the capacitive system. In addition, a credit was given for excess generation above the rated capacity of the plant. The model is based on a summer peaking utility; in Section 5.2 a winter peaking utility is considered.

The comparison of the CB\&I concept with alternate cooling concepts will be based on the incremental cost of dry cooling which refers to the total of all costs attributable to a power plant cooling systems. The incremental cost is referenced to a power plant with a conventional turbine operating at $3.5 \mathrm{in}$. Hg. Steam supply scaling, heat rate scaling and the fuel cost differential are each based on the reference value. The cost model includes the following components.

$$
\begin{aligned}
\text { Incremental cost }= & {[(C C O S+C A C O S+\text { SPCD }+ \text { CAPCST }) * F C R+C O S M+C S T C L} \\
& D E L F C+E X G E N+C M P W P+\text { WATCST }] /(P S I Z E * C A P F * 8760)
\end{aligned}
$$

where

$$
\begin{aligned}
\text { CCOS } & =\text { Cooling System Capital Cost }(\$) \\
\text { CACOS } & =\text { Capacitive System Capital Cost }(\$) \\
\text { SPCD } & =\text { Base Plant Scaling Capital Cost }(\$) \\
\text { CAPCST } & =\text { Replacement Capacity Capital Cost }(\$) \\
\text { FCR } & =\text { Fixed Charge Rate (decimal fraction) } \\
\text { COSM } & =\text { Annual Cost for Maintenance }(\$)
\end{aligned}
$$




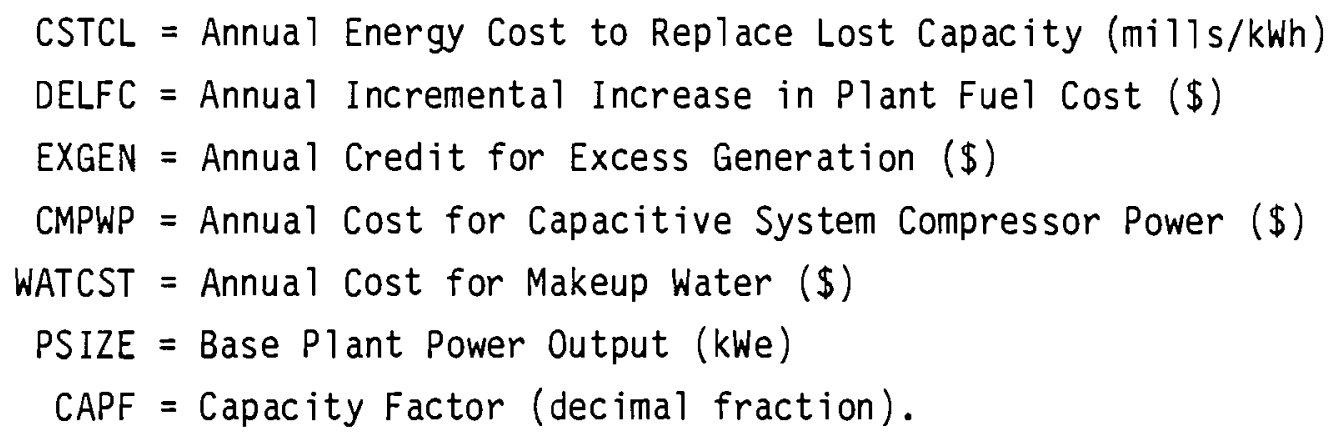

The utility system model assumes that excess generation can be used to displace power produced by a base loaded coal-fired power plant. The value of the displaced power would include the incremental fuel cost saving and variable maintenance cost savings to the base-loaded power plant.

Interest during construction and inflation during construction are not considered. Effects of the dry cooling system's construction schedule are also not considered. The uncertainty involved in defining those items appears to outweigh any additional understanding obtained by including them in a comparative analysis. The costs can be compared either on a first-year operational cost or on a levelized operational cost, which includes consideration of anticipated escalation of operating costs over the life of the plant. The latter approach, using the economic parameter recommended by EPRI for economic projections relating to utility systems, ${ }^{(6)}$ was used in this study. The fixed parameters are identified in the following sections.

\subsubsection{Cooling System Capital Cost}

The cooling system capital cost includes costs for the condenser/ reboiler, piping system and cooling tower. The capital costs include direct materials and labor, general contractor's costs and engineering costs.

\subsubsection{Capacitive System Capital Cost}

The capacitive system capital cost includes costs for the storage tank, ammonia reboilers, ammonia compressor and piping. The capital costs include direct materials and labor, general contractor's costs and engineering costs. 


\subsubsection{Base Plant Scaling Capital Cost}

The incremental base plant scaling capital cost includes three components: steam supply scaling, scaling for heat rates and scaling for auxiliary power. A detailed description of these components is included in Reference 4.

Because alternative turbine designs are not being considered, there will be no steam supply scaling. Scaling for auxiliary power will include auxiliary power for fans and pumps. Both water and ammonia pumps will be included in base plant scaling. Compressor power required for the cooling loop of the capacitive system is not considered for base plant scaling for reasons which will be discussed in Section 5.1.9. Scaling for heat rate effects is handled in a manner similar to that described in Reference 4.

\subsubsection{Replacement Capacity Capital Cost}

The capital cost of replacement capacity is calculated from the difference between the rated $p l$ ant output and the minimum output of the plant due to variations in ambient conditions. For a normal dry-cooled plant the minimum power output will occur during periods of peak ambient temperature. This may not be the case for a capacitive system where the cooling capacity depends on both peak ambient temperature and diurnal temperature variation.

The CB\&I system was sized for the worst-case combination of diurnal temperature variation and peak ambient temperature so that turbine backpressure will not exceed the maximum allowable backpressure, which is $5 \mathrm{in} . \mathrm{Hg}$. The capacitive system will be brought into service as turbine backpressure reaches $5 \mathrm{in} . \mathrm{Hg}$ and will have sufficient capacity to maintain $5 \mathrm{in}$. $\mathrm{Hg}$ backpressure for the most extreme daily ambient temperature profile. At all conditions other than the extreme case, turbine backpressure will not reach $5 \mathrm{in}$. $\mathrm{Hg}$. Therefore, the minimum plant power output will occur at the extreme case.

The capacity penalty for the dry and wet/dry concepts is based on the difference between rated capacity and the output during the single hour of the year with the highest ambient temperature. This is the same procedure used in the BNW-I and BNW-II codes. Replacement power is assumed to be provided by a gas turbine. 


\subsubsection{Annual Cost for Maintenance}

The annual cost of maintenance can be divided into two components: a fixed component, which is a percentage of capital cost, and a variable component dependent on the extent the plant is operating. Because the variable component is included in fuel costs, the term for annual maintenance includes only the fixed component. Annual cost for maintenance does not include any additional cost for cleaning or maintenance of wet/dry surfaces in the wet/dry concepts.

\subsubsection{Annual Energy Cost to Replace Lost Capacity}

The annual energy cost to replace lost capacity is the variable cost associated with the operation of the replacement power gas turbine. This cost includes the costs of fuel and maintenance.

\subsubsection{Annual Incremental Increase in Plant Fuel cost}

The annual incremental increase in plant fuel cost reflects the increased fuel consumption required to operate the cooling tower fans and pumps. The cost is based on the cost of fuel and variable maintenance costs.

\subsubsection{Annual Credit for Excess Generation}

Unlike the utility system model used in BNW-I and II, a credit is given for excess generation. One advantage of the capacitive system is that excess generation is increased during days with moderate ambient temperatures. An accurate comparison of the concepts should include this effect. The conservative method of valuing excess generation is to assume that the excess generation is used to replace power from a base-loaded coal-fired plant. In this case, the excess generation has a value equal to the cost of fuel and variable maintenance for the base-loaded power plant.

BNW-I was modified to include excess generation credit in the optimization methodology. A comparison between an optimized plant where excess generation credit was included and one where excess generation was not included showed that the optimized dry cooling systems were very similar in size. It appears that including a credit for excess generation does have a major impact on the economics of dry cooling but does not affect the optimal design. 


\subsubsection{Annual Cost for Capacitive System Compressor Power}

The ammonia compressor, which is operated when the capacitive system is in the cooling mode, would be used only at night when most utility systems are at off-peak conditions. For this reason, no base plant scaling to cover this need (as was done to provide power for fans and pumps) was included. Furthermore, the power is assumed to be available at a rate of a base-load coal-fired plant, which equals the cost of fuel and variable maintenance for a base-loaded coal-fired power plant.

\subsubsection{Annual Cost for Cooling System Makeup Water}

The annual cost for cooling system makeup water is signficant only for the wet/dry systems where some water is evaporated during periods of high ambient temperature. The cost of water used in this study corresponds to the cost of treating and conveying municipal waste water. This was felt to be a conservative estimate for the cost of makeup water.

\subsection{WINTER PEAKING ECONOMIC MODEL}

In this study, the base case utility model is for a summer peaking utility where the peak demand for power and the minimum capability for power generation due to dry cooling occur at the same time. As a sensitivity study, a model for a winter peaking utility will be considered. The plant is still assumed to be located at Middletown and have performance identical to that used in the summer peaking analysis.

The economic model for a winter peaking utility is similar to that described in Section 5.1 with two variations.

- There is no capacity penalty or replacement energy charge since the peak output of the plant will occur during the time periods with the coldest ambient temperatures. This will roughly correspond to the periods of peak demand for a winter peaking utility.

- Two cases of excess generation will be considered. One will be the same as that discussed in Section 5.1 .8 and will represent the displacement of base-loaded coal-fired power plants. The value of excess generation for 
this case is $15.16 \mathrm{mills} / \mathrm{kwhe}$. For the second case, the excess generation is assumed to coincide with peak demand periods, such as would be the case for a winter peaking utility. In this case the excess generation could be displacing the more expensive peaking units and is assumed to have a value of $27 \mathrm{mills} / \mathrm{kWh}$. This is the average of the incremental fuel and maintenance cost of a base-loaded coal-fired plant and a peaking oil-fired gas turbine.

No capacity credit was given for the increased peak capacity of the drycoded plant which could eliminate the need for an alterate peaking unit. This was because of the difficulty in determining the dry-cooled plants output at peak conditions since peak capacity and a peak demand may not exactly coinside.

It is obvious that dealing with a winter peaking utility is fundamentally more uncertain than a summer peaking utility. This is because one can assume that the summer peak demand will occur at the hottest time period. The converse is not necessarily true of a winter peaking utility where the peak demand may still occur during the day while the peak dry-cooled plant output would occur at night. The assumptions used in this study are reasonable but a detailed analysis of a specific winter peaking utility load curve would be required for a more accurate study.

\subsection{ANALYSIS OF CHICAGO BRIDGE \& IRON COMPANY SYSTEM}

The analysis of the CB\&I system was divided into three tasks: design, performance analysis and economic analysis. Chicago Bridge \& Iron Company had primary responsibility for performing the design and performance analysis; PNL was responsible for the economic analysis.

CB\&I sized the cooling system based on the requirements that turbine backpressure would not exceed $5 \mathrm{in}$. $\mathrm{Hg}$ under the most severe ambient conditions. CB\&I chose $85^{\circ} \mathrm{F}$ for the ambient temperature at which the turbine experiences a backpressure of $5 \mathrm{in.} \mathrm{Hg}$. Above this ambient temperature the capacitive system must provide the excess cooling.

The design conditions were taken from 1978 weather data for Boston, Massachusetts, and represent the most severe combination of ambient temperature 
and diurnal temperature variations. Based on these conditions the capacitive system was sized to ensure that backpressure never exceeded $5 \mathrm{in}$. $\mathrm{Hg}$. At an ambient temperature of $85^{\circ} \mathrm{F}$, CB\&I has assumed a steam condenser initial temperature differance (ITD) of $5^{\circ} \mathrm{F}$ and a cooling tower ITD of $20^{\circ} \mathrm{F}$.

PNL provided the design of the dry cooling system and the water/steam condenser. Because the components of the dry cooling system were common to all of the concepts being considered, it was felt that a consistent comparison would be obtained by having an organization responsible for the design and costing of these components. PNL was provided with performance requirements from CB\&I and these were used as the basis for a point design of an all-dry cooling system, using the BNW-I computer code. The output of the code provided cooling system performance and cost. In addition, the water/steam condenser, used to increase heat rejection during periods of high ambient temperature, was designed by PNL using Heat Exchanger Institute standards for steam surface condensers, which are incorporated into the algorithms developed for BNW-I. It was assumed that the condenser tubes could be located in the condenser/ reboiler shell with no increase in the shell size. The characteristics of the system are shown in Table 5.1. If a separate she11 were required, the capital cost of the CB\&I system would increase by approximately $10 \%$.

Because CB\&I conducted on ly a point design, the capacitive system analyzed in this study cannot be considered an optimal design. This limitation was accepted for a first-order comparison but a more accurate comparison would require that the CB\&I system be optimized in a manner similar to that used in BNW-I and BNW-II for dry and wet/dry cooling systems.

The performance analysis was conducted by CB\&I using a proprietary computer code. The performance was based on a 650-MWe plant located at Boston, Massachusetts, using meteorology typical of Boston. The plant is assumed to have a steam turbine with the performance given in Table 5.2. Plant performance as a function of ambient temperature is given in the Appendix.

The economic analysis was conducted by PNL using the methodology described in Section 3.1. The capital costs associated with the cooling system were taken from the point design done for CB\&I. The capital costs for capacity 
TABLE 5.1. Cooling System Characteristics

\begin{tabular}{|c|c|c|c|c|c|}
\hline & CB\&I & 250 acre- $\mathrm{ft}$ & 500 acre- $\mathrm{ft}$ & 1000 acre-ft & Dry \\
\hline Ammonia Flow Rate ( $\mathrm{lb} / \mathrm{hr})$ & $6,575,000$ & $6,578,000,000$ & $6,470,000$ & $6,470,000$ & $6,425,440$ \\
\hline Air Flow Rate $(\mathrm{lb} / \mathrm{hr})$ & $681,000,000$ & $328,000,000$ & $334,000,000$ & $335,000,000$ & $934,000,000$ \\
\hline Heat Exchange Area $(\mathrm{ft})$ & $14,562,000$ & $15,424,300$ & $15,352,000$ & $15,353,000$ & $22,428,461$ \\
\hline Number of Towers & 6 & 2 & 2 & 2 & 9 \\
\hline Tower Diameter $(\mathrm{ft})$ & 211 & 410 & 410 & 410 & 217 \\
\hline Number of Fans $(28 \mathrm{ft} \mathrm{dia})$ & 156 & 84 & 86 & 86 & 266 \\
\hline
\end{tabular}


penalty and plant scaling were calculated based on the performance information provided by CB\&I. The capital cost of the capacitive system was determined by CB\&I using vender cost information. PNL supplied overheads and profit factors for use in costing the CB\&I system. Other operating costs were determined from the performance data provided by CB\&I.

TABLE 5.2. Middletown Power Plant Turbine Performance

\begin{tabular}{|c|c|c|c|}
\hline $\begin{array}{c}\text { Turbine } \\
\text { Exhaust } \\
\text { Backpressure } \\
\text { (in. } \mathrm{Hg} \text { ) } \\
\end{array}$ & $\begin{array}{l}\text { Turbine } \\
\text { Generator } \\
\text { Output } \\
\text { (kWe) } \\
\end{array}$ & $\begin{array}{l}\text { Heat Rate } \\
\text { (Btu/kWh) }\end{array}$ & $\begin{array}{l}\text { Heat Rejection } \\
\left.\text { (Btu } / \mathrm{hr} \times 10^{-6}\right) \\
\end{array}$ \\
\hline 1.0 & 660,832 & 8801 & 2979 \\
\hline 1.5 & 660,082 & 8811 & 2482 \\
\hline 2.0 & 659,085 & 8824 & 2985 \\
\hline 2.5 & 657,016 & 8852 & 2992 \\
\hline 3.0 & 653,816 & 8896 & 3003 \\
\hline 3.5 & 650,000 & 8945 & 3016 \\
\hline 4.0 & 645,272 & 9013 & 3032 \\
\hline 4.5 & 640,065 & 9087 & 3050 \\
\hline 5.0 & 634,402 & 9168 & 3069 \\
\hline
\end{tabular}

\subsection{ANALYSIS OF DRY AND WET/DRY SYSTEMS}

PNL was responsible for the design, performance analysis and economic analysis of the dry and wet/dry cooling systems. The dry cooling system was designed using BNW-I ${ }^{(4)}$ and the wet/dry cooling system was designed using BNW-II. (5)

The dry system used the Curtiss-Wright surface and circular tower arrangement. The wet/dry system used the HOTERV surface. Three wet/dry cooling systems were designed, each based on a different allowable annual water usage. The three annual water usages were $250 \mathrm{acre}-\mathrm{ft}, 500 \mathrm{acre}-\mathrm{ft}$ and 1000 acre-ft, which correspond to $4 \%, 8 \%$ and $15 \%$ evaporative cooling, respectively. The characteristics of the dry system and the three wet/dry systems are shown on Table 5.1 . 
It should be noted that the dry and wet/dry designs are not optimal designs. The BNW-I and BNW-II computer codes use a design ambient temperature, which is the temperature at which the plant produces its rated output. The turbine backpressure at design temperature is not necessarily the design turbine backpressure of $3.5 \mathrm{Hg}$. If the backpressure at the design temperature is different from the design backpressure of the turbine, then the plant size is scaled up or down to account for the improved or reduced turbine heat rate. This procedure, coupled with the optimization methodology used in BNW-I and BNW-II, tended to produce optimized designs with design temperature backpressures substantially below the design backpressure. Although this procedure is correct, the CB\&I design procedure was based on having the turbine design backpressure occur at the design ambient temperature. In order to have consistent design methodology, it was decided that the dry and wet/dry designs would be designed in such a way that the turbine design in backpressure occurred at the design ambient temperature. This was done by increasing the design temperature. The result was that the dry and wet/dry designs were based on nonoptimal design temperatures, which produced higher incremental costs then for an optimized design. Design temperature is discussed more completely in References 4 and 5. 


\subsection{GROUND RULES AND ASSUMPTIONS}

This section will discuss the location and characteristics of the hypothetical power plant and present the economic ground rules.

\subsection{POWER PLANT DESCRIPTION AND LOCATION}

In this study, the cooling systems were designed for a 650-MWe coal-fired power plant with appropriate flue gas desulfurization equipment. The area in front of the plant is assumed to be used for transformers, switchgear and other electrical equipment. The area behind the plant is assumed to be used for flue gas treatment and coal handing. The cooling tower complex is assumed to be located on the side of the plant with a distance of $500 \mathrm{ft}$ between the condenser and cooling tower complex. Capital costs, maintenance costs and capacity factors were taken from Reference 6 . The turbine heat rate was supplied by CB\&I.

The power plant is assumed to be located in Middletown, a hypothetical site close to Boston, Massachusetts. For this study, meteorology similar to that for Boston will be assumed. Table 6.1 presents site meteorology used for this study. The site is assumed to have cooling tower makeup water available for the wet/dry system. The water is assumed to come from treated municipal waste water.

Earlier work with capacitive systems indicated that a capacitive system becomes more attractive in more severe sites, particularly sites with high ambient temperatures and large diurnal temperature variations. This is true when compared to an all-dry cooling system. Because a wet/dry cooling system is also a peak shaving device, it is not clear how variations in site meteorology will affect the comparison between the CB\&I capacitive system and a wet/ dry cooling system.

The New England site was chosen because of the conservative meteorology. If the CB\&I capacitive system were competitive with dry/wet cooling at Boston, it would be competitive at most sites. 
TABLE 6.1. Annual Temperature Duration Data, Northeast Site

\begin{tabular}{|c|c|c|c|c|c|}
\hline \multirow{2}{*}{$\begin{array}{l}\text { Temp. } \\
\text { (OF) } \\
\end{array}$} & \multicolumn{2}{|c|}{ Average Annual Duration } & \multirow[b]{2}{*}{$\begin{array}{l}\text { Temp. } \\
\text { (OF) }\end{array}$} & \multicolumn{2}{|c|}{ Average Annual Duration } \\
\hline & $\begin{array}{c}\text { Dry-Butb } \\
(\mathrm{hr}) \\
\end{array}$ & $\begin{array}{l}\text { Wet-Bulb } \\
(\mathrm{hr}) \\
\end{array}$ & & $\begin{array}{c}\text { Dry-Bulb } \\
(\mathrm{hr}) \\
\end{array}$ & $\begin{array}{l}\text { Wet-BuTb } \\
(\mathrm{hr}) \\
\end{array}$ \\
\hline 99.5 & 0.7 & -- & 41.5 & 321.7 & 326.4 \\
\hline 97.5 & 2.1 & -- & 39.5 & 331.3 & 365.1 \\
\hline 95.5 & 6.2 & -- & 37.5 & 332.8 & 376.1 \\
\hline 93.5 & 10.9 & -- & 35.5 & 324.1 & 371.4 \\
\hline 91.5 & 17.2 & -- & 33.5 & 297.2 & 344.4 \\
\hline 89.5 & 25.9 & -- & 31.5 & 250.3 & 333.0 \\
\hline 87.5 & 40.0 & -- & 29.5 & 220.5 & 277.6 \\
\hline 85.5 & 61.9 & -- & 27.5 & 176.0 & 254.4 \\
\hline 83.5 & 78.5 & -- & 25.5 & 158.9 & 223.0 \\
\hline 81.5 & 98.4 & -- & 23.5 & 124.8 & 180.3 \\
\hline 79.5 & 121.7 & 1.1 & 21.5 & 103.9 & 151.6 \\
\hline 77.5 & 152.6 & 10.3 & 19.5 & 89.6 & 129.3 \\
\hline 75.5 & 203.3 & 36.8 & 17.5 & 73.0 & 105.1 \\
\hline 73.5 & 238.2 & 85.2 & 15.5 & 58.2 & 84.9 \\
\hline 71.5 & 274.8 & 155.1 & 13.5 & 43.8 & 65.1 \\
\hline 69.5 & 318.8 & 229.4 & 11.5 & 33.8 & 54.4 \\
\hline 67.5 & 331.3 & 279.6 & 9.5 & 27.3 & 38.4 \\
\hline 65.5 & 341.2 & 340.7 & 7.5 & 18.6 & 28.3 \\
\hline 63.5 & 327.9 & 356.2 & 5.5 & 11.9 & 19.4 \\
\hline 61.5 & 321.0 & 370.7 & 3.5 & 6.9 & 11.6 \\
\hline 59.5 & 319.8 & 413.6 & 1.5 & 4.3 & 6.5 \\
\hline 57.5 & 313.2 & 371.3 & -0.5 & 2.7 & 3.2 \\
\hline 55.5 & 308.3 & 360.6 & -2.5 & 2.4 & 2.9 \\
\hline 53.5 & 299.5 & 347.0 & -4.5 & 0.5 & 1.9 \\
\hline 51.5 & 292.9 & 324.3 & -6.5 & 0.1 & 0.1 \\
\hline 49.5 & 305.5 & 332.1 & -8.5 & 0.1 & 0.1 \\
\hline 47.5 & 311.6 & 322.6 & -10.5 & 0.1 & 0.1 \\
\hline 45.5 & 315.1 & 337.8 & -12.5 & 0.1 & 0.1 \\
\hline 43.5 & 306.6 & 330.9 & & & \\
\hline
\end{tabular}


TABLE 6.2. Modified Economic and Technical Design Conditions (January 1979 dollars)

\begin{tabular}{|c|c|}
\hline Design Temperature & $55^{\circ} \mathrm{F}$ \\
\hline Dry Bulb Air Temperature & Supplied by CB\&I \\
\hline Wet Bulb Air Temperature & Supplied by CB\&I \\
\hline Base Gross Turbine Output at $3.5 \mathrm{in.} \mathrm{Hg}$ & $650 \mathrm{MW}$ \\
\hline Base Gross Turbine Efficiency & 0.4238 \\
\hline Capacity Factor & 0.70 \\
\hline Fixed Charge Rate & 0.18 \\
\hline Fixed Maintenance Cost (Ratio to Capital Cost) & $0.004(0.008)^{(a)}$ \\
\hline Site Elevation & $100 \mathrm{ft}$ \\
\hline Construction Cost Multiplier & 1.0 \\
\hline Fuel cost (includes variable 0\&M) & $1.228 \$ / \mathrm{mBtu}(2.948)$ \\
\hline Replacement Power Cost & $39 \mathrm{mills} / \mathrm{kWh}(94.40)$ \\
\hline Power Plant Construction Cost & $\$ 742 / \mathrm{kW}$ \\
\hline Cost of Steam Supply System & $\$ 247 / \mathrm{kW}$ \\
\hline Capacity Charge & $\$ 170 / \mathrm{kW}$ \\
\hline Distance from Tower to Condenser & $500 \mathrm{ft}$ \\
\hline Cost of Deluge Water & $\$ 325 /$ acre-ft $(\$ 613)$ \\
\hline General Inflation Rate & $6 \%$ \\
\hline Fuel Inflation Rate & $8 \%$ \\
\hline Allowed Water Consumption & Variable ( 0 to 3000 acre-ft) \\
\hline $\begin{array}{l}\text { Cost of Off-Peak Auxiliary Energy or Value } \\
\text { of Excess Power }\end{array}$ & $15.16 / \mathrm{mill} / \mathrm{s} / \mathrm{kWh}(35.03)$ \\
\hline Pump Efficiency & $85 \%$ \\
\hline Fue 1 Leveling Factor & 2.471 \\
\hline Maintenance Levelizing Factor & 1.886 \\
\hline
\end{tabular}

(a) Levelized value in parentheses 
In addition to assumptions on plant characteristics and site it was also assumed that large (650-MWe) high backpressure turbines would not be available. Earlier studies have shown that a capacitive system installed with an all-dry cooling system, augmented with capacitive water cooling, loses its performance advantage when compared to conventional water-circulating dry cooling systems, if high backpressure turbines are used. It is not clear how the use of high backpressure turbines would affect the comparison between the CB\&I system and other ammonia circulating dry cooling concepts.

\subsection{ECONOMIC GROUND RULES}

In general, the economic variables were taken from Reference 6 for a coalfired power plant. Fuel costs, replacement capacity, capital costs, fixed charge rates and escalation rates were also taken from Reference 6 . Table 6.2 includes the economic variables used in this study. All calculations were performed using 1/1/1976 dollars because all of the results of BNW-I and BNW-II are in $1 / 1 / 1976$ dollars. The results were escalated at $6 \%$ per year to represent $1 / 1 / 1979$ do 11 ars. 


\subsection{RESULTS}

Based on the methodology described in Section 5.0 and using the ground rules discussed in Section 6.0, the incremental cost of dry cooling was calculated for the CB\&I system and alternate dry cooling systems. The results are presented in this section.

\subsection{RESULTS OF SUMMER PEAKING UTILITY ANALYSIS}

The results of the capital cost analysis are presented on Table 7.1. It should be noted that the cooling system capital cost for the three wet/dry systems is almost equal. In all three cases the computer program optimized practically the same cooling system design. The variation in cost is due the increased cost of deluge piping for the larger water usage. In a more extreme climate a greater variation among wet/dry designs would be expected. The results show that the capital cost of the CB\&I system is substantially below the cost of the all-dry system but still above the cost of the wet/dry systems.

The results of the annual cost analysis are shown on Table 7.2. The dominant cost components are the fixed charge on capital and the credit for excess generation. The contributions due to compressor power and maintenance are relatively insignificant.

The incremental cost of dry cooling calculated on a levelized basis in $1 / 1 / 1979$ dollars is presented in Figure 7.1. The CB\&I system demonstrates a substantial reduction in incremental cost when compared to the all-dry cooling system, and is nearly competitive with the wet/dry systems. The incremental cost of the CB\&I system is $7 \%$ more expensive than the least-cost wet/dry system. Considering the accuracy of the assumptions used in this study, it appears that the CB\&I system has approximately the same incremental cost as wet/dry systems. 
TABLE 7.1. Capital Cost Summary (1/1/76 dollars)

\begin{tabular}{|c|c|c|c|c|c|}
\hline Cost Component & CB\&I & Dry & $\begin{array}{c}\text { Wet/Dry } \\
(250 \text { acre-ft) }\end{array}$ & $\begin{array}{c}\text { Wet/Dry } \\
(500 \text { acre-ft) }\end{array}$ & $\begin{array}{c}\text { Wet/Dry } \\
(1000 \text { acre-ft) }\end{array}$ \\
\hline Cooling System Capital Cost & $31,829,000$ & $45,802,000$ & $32,794,000$ & $32,454,000$ & $32,698,000$ \\
\hline Capacitive System Capital Cost & $4,201,000$ & -- & -- & - & -- \\
\hline Capacity Penalty & $2,221,000$ & $2,629,000$ & 298,000 & -- & -- \\
\hline Steam Supply Scaling & -- & - & 66,000 & & 66,000 \\
\hline Base Plant Heat Rate Scaling & -- & 996,000 & 311,000 & $-1,079,000$ & $-1,079,000$ \\
\hline Base Plant Auxiliary Scaling & $3,626,000$ & $\begin{array}{l}\text { Included in heat } \\
\text { rate scaling) }\end{array}$ & & & \\
\hline TOTAL & $41,877,000$ & $49,457,000$ & $36,817,000$ & $34,884,000$ & $35,143,000$ \\
\hline
\end{tabular}

TABLE 7.2. Annual Cost Summary (Levelized, 1/1/76 dollars)

\begin{tabular}{|c|c|c|c|c|c|}
\hline Cost Component & CB\&I & Dry & $\begin{array}{c}\text { Wet/Dry } \\
(250 \text { acre-ft })\end{array}$ & $\begin{array}{c}\text { Wet/Dry } \\
(500 \text { acre-ft })\end{array}$ & $\begin{array}{c}\text { Wet/Dry } \\
(1000 \mathrm{acre}-\mathrm{ft})\end{array}$ \\
\hline Fixed Charge on Capital & $7,538,000$ & $8,902,000$ & $6,627,000$ & $6,279,000$ & $6,326,000$ \\
\hline Maintenance Charge & 335,000 & 396,000 & 294,000 & 280,000 & 280,000 \\
\hline Energy Penalty & 497,000 & 118,000 & 155,000 & -- & - \\
\hline Additional Base Plant Fuel & 715,000 & 639,000 & 695,000 & 717,000 & 712,000 \\
\hline Excess Generation & $-1,860,000$ & $-725,000$ & $-1,051,000$ & $-718,000$ & $-917,000$ \\
\hline Compressor Power & 41,000 & -- & -- & -- & -- \\
\hline Water Costs & -- & - & 130,000 & 258,000 & 519,000 \\
\hline TOTAL & $7,319,000$ & $9,330,000$ & $6,850,000$ & $6,816,000$ & $6,931,000$ \\
\hline
\end{tabular}




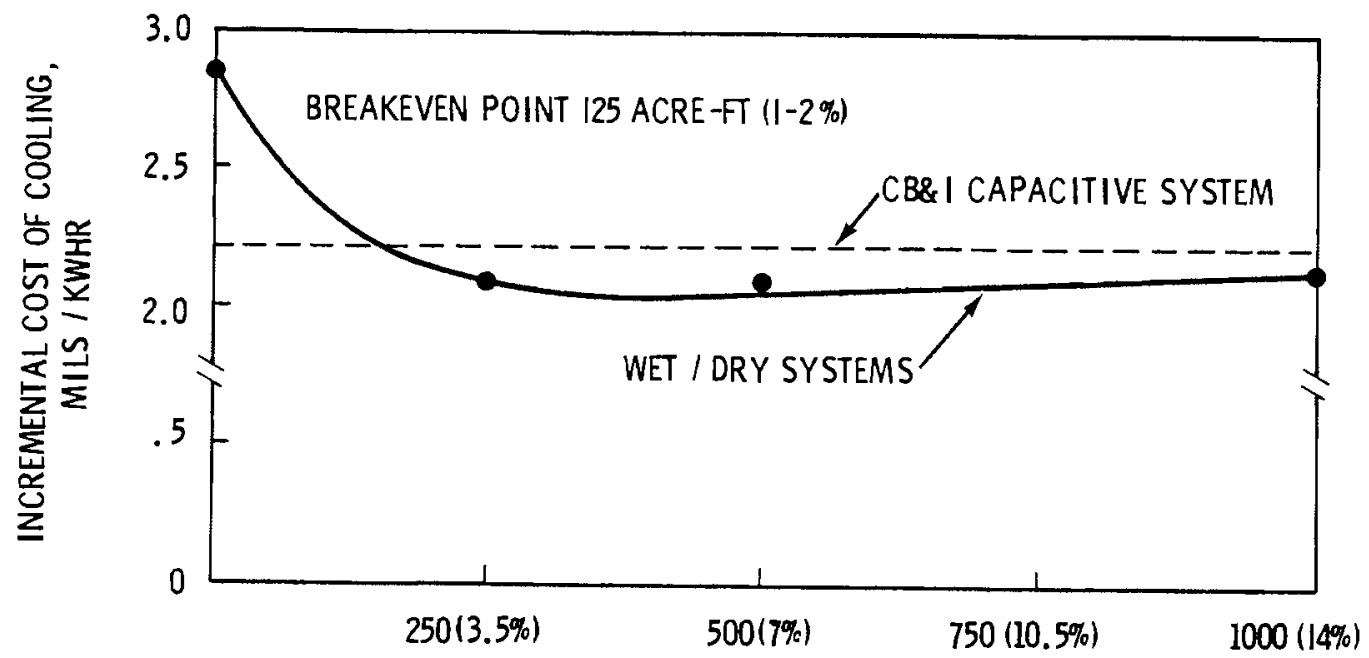

FIGURE 7.1. Incremental cost as a Function of Water Consumption

Table 7.3 shows that the incremental cost of cooling increases with greater water usage. This is due to the high cost of cooling tower makeup water. When water cost is not considered, the incremental cost of cooling decreases with increased water usage.

\subsection{RESULTS OF WINTER PEAKING UTILITY ANALYSIS}

The results of the capital cost analysis for a winter peaking utility are presented in Table 7.4. The only difference between Table 5.1 for summer peaking utilities and Table 7.4 for winter peaking utilities is that the capacity penalty has been eliminated in Table 7.4.

The results of the levelized annual cost analysis are shown in Tables 7.5 and 7.6. Table 7.6 assumes an excess generation credit of $15.15 \mathrm{mills}$ ( 35 mills when levelized) and corresponds to the displacement of a base-loaded coal-fired power generation. Table 5.6 assumes an excess generation credit of $27 \mathrm{mills}$ ( $64.7 \mathrm{mills}$ when levelized) and corresponds to the displacement of both base-loaded coal-fired power generation and oil-fired gas turbine peaking units.

The results of the analysis indicate that the CB\&I system demonstrates a slightly lower cost than any dry or wet/dry concept when excess generation is 
TABLE 7.3. Summary of Results

\begin{tabular}{|c|c|c|c|c|c|}
\hline $\begin{array}{c}\text { Water Us age } \\
\text { (acre-ft) }\end{array}$ & Computer Code & $\begin{array}{c}\text { Design Temperature } \\
\text { (OF) }\end{array}$ & $\begin{array}{c}\text { Backpressure at } \\
\text { Design Temperature } \\
\text { (in. } \mathrm{Hg})\end{array}$ & $\begin{array}{c}\text { Cooling System } \\
\text { Capital Cost } \\
\left(\$ 10^{6}\right) \\
\end{array}$ & $\begin{array}{c}\text { Incremental Cost } \\
\text { Levelized } 1 / 1 / 79 \text { dollars } \\
\text { (mill/s/kWh) }\end{array}$ \\
\hline 0 & BNW-1 & 80 & 3.03 & 45.8 & 2.831 \\
\hline 250 & BNW-II & 68 & 3.46 & 32.8 & 2.078 \\
\hline 500 & $B N W-I I$ & 65 & 3.27 & 32.5 & 2.068 \\
\hline 1000 & $B N W-I I$ & 65 & 2.79 & 32.7 & 2.103 \\
\hline CB\&I & BNW-I & 71 & 3.5 & 31.8 & 2.204 \\
\hline
\end{tabular}

TABLE 7.4. Capital Cost Summary - Winter Peaking Utility (1/1/76 dollars)

Cost Component

Cooling System Capital Cost

Capacitive System Capital Cost

Capacity Penalty

Steam Supply Scaling

Base Plant Heat Rate Scaling

Base Plant Auxiliary Scaling

TOTAL

\begin{tabular}{cc} 
CB\&I & Dry \\
\cline { 1 - 1 } $31,829,000$ & $45,803,000$ \\
$4,151,000$ & -- \\
-- & -- \\
-- & -- \\
-- & 966,000 \\
$3,626,000$ & Included in heat \\
& rate scal ing \\
\hline
\end{tabular}

$39,606,000$

$46,769,000$
Wet/Dry $(250$ acre-ft

$$
32,794,000
$$

-.

$--$

66,000

311,000

$36,519,000$
Wet/Dry

$(500$ acre-ft)

$32,454,000$

--

$--$

66,000

$-1,079,000$

$3,348,000$

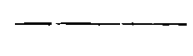

$34,884,000$
$35,143,000$

Wet/Dry $(1000$ acre-ft $)$

$32,692,000$

$--$

--

66,000

$-1,079,000$

$3,444,000$

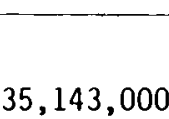


TABLE 7.5. Annual Levelized Cost Summary - Winter Peaking Utility (1/1/79 dollars). Case I - Excess generation credit of $35 \mathrm{mi} 11 \mathrm{~s} / \mathrm{kWh}$.

\begin{tabular}{|c|c|c|c|c|c|}
\hline Cost Component & CB\&I & Dry & $\begin{array}{c}\text { Wet/Dry } \\
(250 \text { acre-ft) }\end{array}$ & $\begin{array}{c}\text { Wet/Dry } \\
(500 \text { acre-ft) }\end{array}$ & $\begin{array}{c}\text { Wet } / \text { Dry } \\
(1000 \mathrm{acre}-\mathrm{ft})\end{array}$ \\
\hline $\begin{array}{l}\text { Fixed Charge on Capital } \\
\text { Maintenance Charge } \\
\text { Energy Penalty } \\
\text { Additional Base Plant Fuel } \\
\text { Excess Generation } \\
\text { Compressor Power } \\
\text { Water Costs }\end{array}$ & $\begin{array}{r}7,129,000 \\
316,000 \\
-- \\
715,000 \\
-1,860,000 \\
41,000 \\
-- \\
\end{array}$ & $\begin{array}{r}8,418,000 \\
374,000 \\
-- \\
639,000 \\
-863,000 \\
-- \\
-- \\
\end{array}$ & $\begin{array}{r}6,573,000 \\
291,000 \\
-- \\
675,000 \\
-1,050,000 \\
-- \\
130,000 \\
\end{array}$ & $\begin{array}{r}6,279,000 \\
278,000 \\
-- \\
717,000 \\
-718,000 \\
-- \\
258,000 \\
\end{array}$ & $\begin{array}{r}6,385,740 \\
280,000 \\
-- \\
712,000 \\
-917,000 \\
-- \\
517,000 \\
\end{array}$ \\
\hline & $6,341,000$ & $8,568,000$ & $6,689,000$ & $6,814,000$ & $6,920,000$ \\
\hline $\begin{array}{l}\text { Incremental Cost of } \\
\text { Dry Cooling (mills } / \mathrm{kWh})\end{array}$ & 1.603 & 2.600 & 1.679 & 1.723 & 1.749 \\
\hline
\end{tabular}

TABLE 7.6. Annual Cost Summary - Winter Peaking Utility (1/1/79 dollars). Case II - Excess generation value - $64.7 \mathrm{mi}] \mathrm{ls} / \mathrm{kWh}$.

\begin{tabular}{|c|c|c|c|c|c|}
\hline Cost Component & CB\&I & Dry & $\begin{array}{c}\text { Wet/Dry } \\
(250 \mathrm{acre}-\mathrm{ft})\end{array}$ & $\begin{array}{c}\text { Wet/Dry } \\
(500 \text { acre-ft) }\end{array}$ & $\begin{array}{c}\text { Wet } / \text { Dry } \\
(1000 \text { acre-ft) }\end{array}$ \\
\hline $\begin{array}{l}\text { Fixed Charge on Capital } \\
\text { Maintenance Charge } \\
\text { Energy Penalty } \\
\text { Additional Base Plant Fuel } \\
\text { Excess Generaion } \\
\text { Compressor Power } \\
\text { Water Costs }\end{array}$ & $\begin{array}{r}7,129,000 \\
316,000 \\
-- \\
715,000 \\
-3,435,000 \\
41,000 \\
-- \\
\end{array}$ & $\begin{array}{r}8,418,000 \\
374,000 \\
-- \\
639,000 \\
-1,595,000 \\
-- \\
\end{array}$ & $\begin{array}{r}6,573,000 \\
291,000 \\
-- \\
695,000 \\
-1,941,000 \\
-- \\
120,000 \\
\end{array}$ & $\begin{array}{r}6,279,000 \\
278,000 \\
7- \\
717,000 \\
-1,326,000 \\
-- \\
258,000 \\
\end{array}$ & $\begin{array}{r}6,326,000 \\
280,000 \\
-- \\
712,000 \\
-1,073,000 \\
-- \\
519,000\end{array}$ \\
\hline & $4,766,000$ & $7,836,000$ & $5,748,000$ & $6,206,000$ & $6,144,000$ \\
\hline $\begin{array}{l}\text { Incremental Cost of } \\
\text { Dry Cooling (mills/kwh) }\end{array}$ & 1.205 & 1.9967 & 1.453 & 1.569 & 1.553 \\
\hline
\end{tabular}


credited at $15.16 \mathrm{mills} / \mathrm{kwh}$. However, considering the accuracy of the assumption, one would conclude that the CB\&I system and the wet/dry systems have essentially the same cost. When excess generation is credited at $27 \mathrm{mills} / \mathrm{kWh}$, the CB\&I system shows a significant decrease in the cost of dry cooling when compared to either the dry or wet/dry concepts. As with the summer peaking utility analysis, the dominant cost components are fixed charge on capital and excess generation credit, with excess generation credit becoming even more significant. 


\section{REFERENCES}

1. E. C. Guyer, An Engineering and Economic Evaluation of Some Mixed Mode Waste Heat Rejection Systems. Ph.D Thesis, Massachusetts Institute of Technology, Cambridge, MA, 1976.

2. M. K. Drost and R. T. Allemann, An Engineering and Cost Analys is of a Dry Cooling System Augmented with a Thermal Storage Pond. PNL-2745, Pacific Northwest Laboratory, Richland, WA 99352, September 1978.

3. B. C. Fryer, D. J. Braun, D. J. Braun, L. E. Wiles and D. W. Faletti, An Engineering and Cost Comparison of Three Different All-Dry Cooling Systems. BNWL-2121, Pacific Northwest Laboratory, Richland, WA 99352 , September 1976.

4. D. J. Braun, D. J. Braun, L. E. Wiles, W. V. DeMier and D. W. Faletti, A User's Manual for the BNW-I Optimization Code for Dry-Cooled Power Plants, Volume I. BNWL-2180 Vol-I, Pac if ic Northwest Laboratory, Richland, WA 99352, January 1977.

5. D. J. Braun, J. A. Bamberger, D. J. Braun, D. W. Faletti, L. E. Wiles, A User's Manual for the BNW-II Optimization Code for Dry/Wet-Cooled Power Plants, Volume I. PNL-2674 Vol-I, Pacific Northwest Laboratory, Richland, WA 99352 , May 1978.

6. Technical Assessment Group of the EPRI Planning Staff, Technical Assessment Guide. EPRI PS-866-SR, Electric Power Research Institute, Palo A1to, CA 94304 , June 1978. 

APPENDIX

650-MW FOSSIL PLANT EVALUATED ANNUAL PERFORMANCE WITH CB\&I MECHANICAL DRAFT COOLING TOWER SYSTEM 
TABLE A.1. 650-MW Fossil Plant Evaluated Annual Performance with CB\&I Mechanical Dract Dry Cooling Tower System

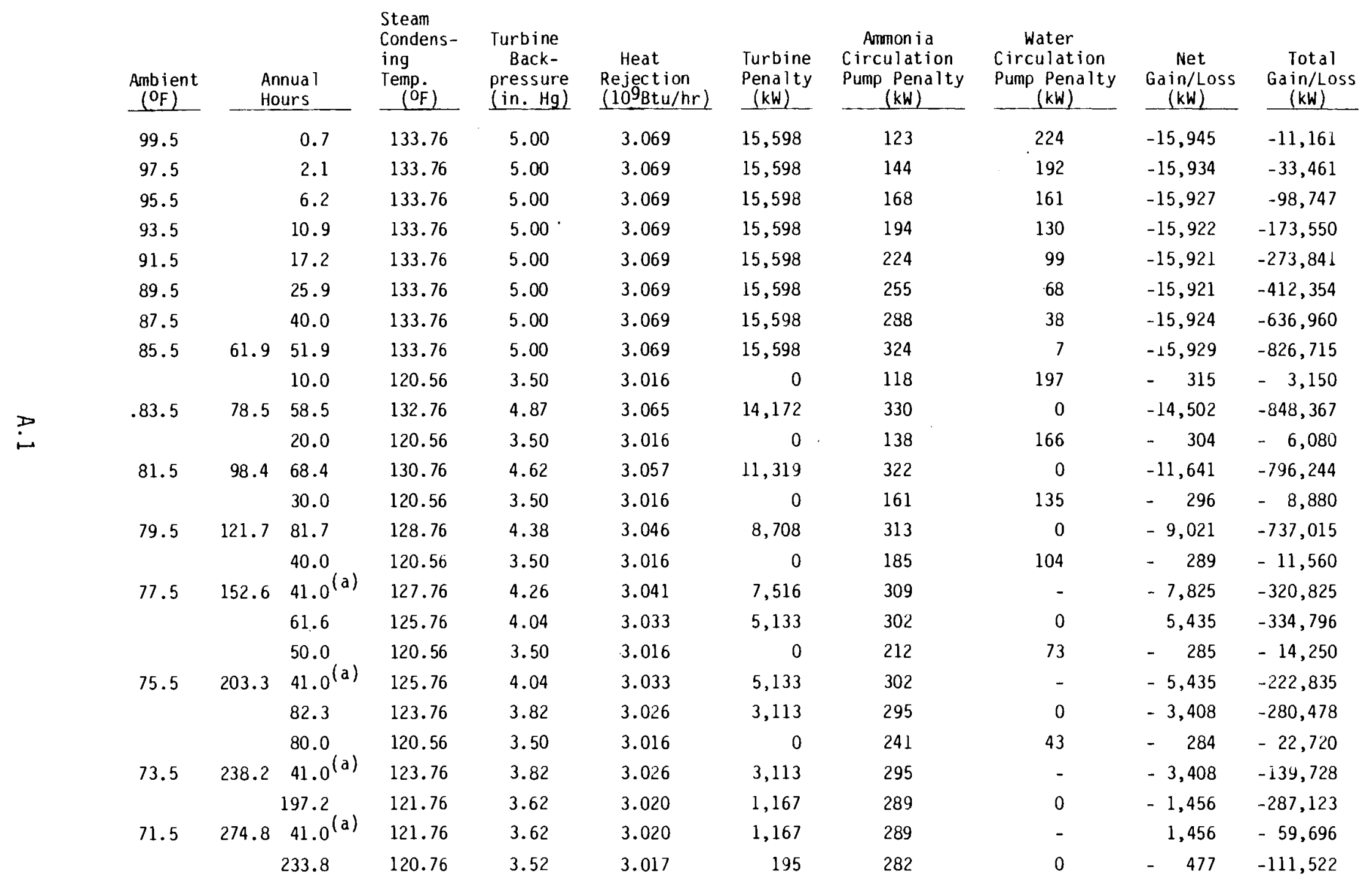

(a) Total peak shaving system cooling system energy consumption (including penalties of $334 \mathrm{~kW}, 3743 \mathrm{~kW}$ for water pump and ammonia compressor). 
TABLE A.1. (contd)

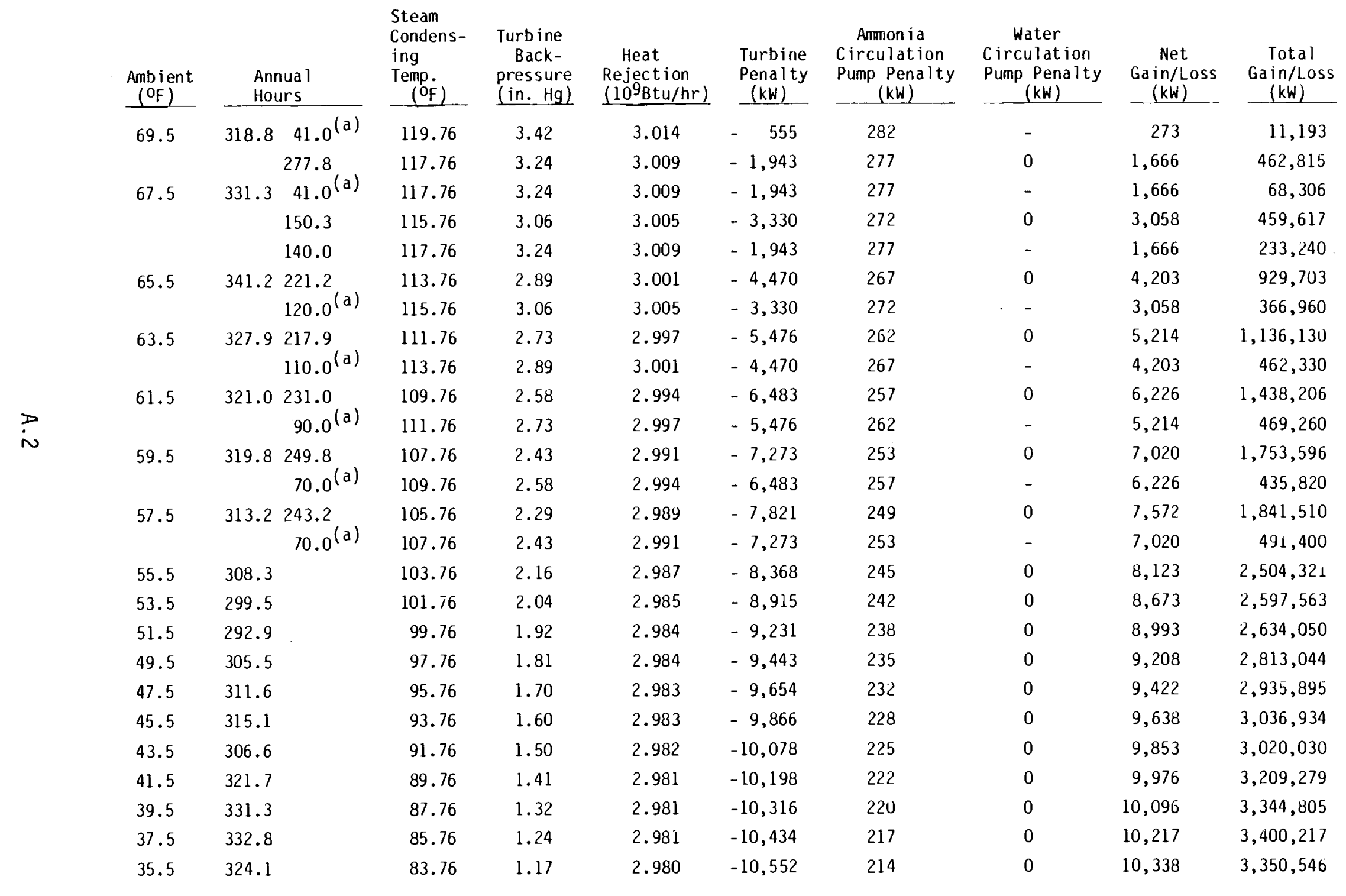

(a) Total peak shaving system cooling system energy consumption (including penalties of $334 \mathrm{~kW}, 3743 \mathrm{~kW}$ for water pump and ammonia compressor). 
TABLE A.1. (contd)

\begin{tabular}{|c|c|c|c|c|c|c|c|c|c|}
\hline $\begin{array}{l}\text { Amb ient } \\
\text { (OF) }\end{array}$ & $\begin{array}{l}\text { Annual } \\
\text { Hours }\end{array}$ & $\begin{array}{l}\text { Steam } \\
\text { Condens- } \\
\text { ing } \\
\text { Temp. } \\
\quad(\mathrm{OF}) \\
\end{array}$ & $\begin{array}{l}\text { Turbine } \\
\text { Back } \\
\text { pressure } \\
\text { (in. } \mathrm{Hg} \text { ) }\end{array}$ & $\begin{array}{c}\text { Heat } \\
\text { Rejection } \\
\left(10^{9} \text { Btu/hr) }\right.\end{array}$ & $\begin{array}{l}\text { Turbine } \\
\text { Penalty } \\
\text { (kW) }\end{array}$ & $\begin{array}{c}\text { Ammonia } \\
\text { Circulation } \\
\text { Pump Penalty } \\
\text { (kW) }\end{array}$ & $\begin{array}{c}\text { Water } \\
\text { Circulation } \\
\text { Pump Penalty } \\
\text { (kW) } \\
\end{array}$ & $\begin{array}{c}\text { Net } \\
\text { Ga in/Loss } \\
(\mathrm{kW})\end{array}$ & $\begin{array}{c}\text { Total } \\
\text { Gain/Loss } \\
(\mathrm{kW})\end{array}$ \\
\hline 33.5 & 297.2 & 81.76 & 1.09 & 2.980 & $-10,671$ & 212 & 0 & 10,459 & $3,108,415$ \\
\hline 31.5 & 250.3 & 79.76 & 1.02 & 2.979 & $-10,789$ & 209 & 0 & 10,580 & $2,648,174$ \\
\hline 29.5 & 220.5 & 78.76 & 0.99 & 2.979 & $-10,848$ & 207 & 0 & 10,641 & $2,346,340$ \\
\hline 27.5 & 176.0 & 78.76 & 0.99 & 2.979 & $-10,848$ & 207 & 0 & 10,641 & $1,872,816$ \\
\hline 25.5 & 158.9 & 78.76 & 0.99 & 2.979 & $-10,848$ & 207 & 0 & 10,641 & $1,690,855$ \\
\hline 23.5 & 124.8 & 78.76 & 0.99 & 2.979 & $-10,848$ & 207 & 0 & 10,641 & $1,327,997$ \\
\hline 21.5 & 103.9 & 78.76 & 0.99 & 2.979 & $-10,848$ & 207 & 0 & 10,641 & $1,105,600$ \\
\hline 19.5 & 89.6 & 78.76 & 0.99 & 2.979 & $-10,848$ & 207 & 0 & 10,641 & 953,433 \\
\hline 17.5 & 73.0 & 78.76 & 0.99 & 2.979 & $-10,848$ & 207 & 0 & 10,641 & 776,793 \\
\hline 15.5 & 58.2 & 78.76 & 0.99 & 2.979 & $-10,848$ & 207 & 0 & 10,641 & 619,306 \\
\hline 13.5 & 43.8 & 78.76 & 0.99 & 2.979 & $-10,848$ & 207 & 0 & 10,641 & 466,076 \\
\hline 11.5 & 33.8 & 78.76 & 0.99 & 2.979 & $-10,848$ & 207 & 0 & 10,641 & 359,666 \\
\hline 9.5 & 27.3 & 78.76 & 0.99 & 2.979 & $-10,848$ & 207 & 0 & 10,641 & 290,499 \\
\hline 7.5 & 18.6 & 78.76 & 0.99 & 2.979 & $-10,848$ & 207 & 0 & 10,641 & 197,922 \\
\hline 5.5 & 11.9 & 78.76 & 0.99 & 2.979 & $-10,848$ & 207 & 0 & 10,641 & 126,628 \\
\hline 3.5 & 6.9 & 78.76 & 0.99 & 2.979 & $-10,848$ & 207 & 0 & 10,641 & 73,423 \\
\hline 1.5 & 4.3 & 78.76 & 0.99 & 2.979 & $-10,848$ & 207 & 0 & 10,641 & 45,756 \\
\hline-0.5 & 2.7 & 78.76 & 0.99 & 2.979 & $-10,848$ & 207 & 0 & 10,641 & 28,730 \\
\hline-2.5 & 2.4 & 78.76 & 0.99 & 2.979 & $-10,848$ & 207 & 0 & 10,641 & 25,538 \\
\hline-4.5 & 0.5 & 78.76 & 0.99 & 2.979 & $-10,848$ & 207 & 0 & 10,641 & 5,320 \\
\hline-6.5 & 0.1 & 78.76 & 0.99 & 2.979 & $-10,848$ & 207 & 0 & 10,641 & 1,064 \\
\hline-8.5 & 0.1 & 78.76 & 0.99 & 2.979 & $-10,848$ & 207 & 0 & 10,641 & 1,064 \\
\hline-10.5 & 0.1 & 78.76 & 0.99 & 2.979 & $-10,848$ & 207 & 0 & 10,641 & 1,064 \\
\hline-12.5 & 0.1 & 78.76 & 0.99 & 2.979 & $-10,848$ & 207 & 0 & 10,641 & 1,064 \\
\hline & & & & & & & & in & $\frac{-3,195,342}{51,613,813}$ \\
\hline
\end{tabular}

(a) Total peak shaving system cooling system energy consumption (including penalties of $334 \mathrm{~kW}, 3743 \mathrm{~kW}$ for water pump and ammonia compressor). 


.


PNL-3272

UC -12

\section{OISTRIBUTION}

No. of

Copies

OFFSITE

A. A. Churm

Chicago Patent Group

9800 South Cass Avenue

Argonne, IL 60439

27 DOE Technical Information Center

10 I. Helms

U.S. Department of Energy

Division of Advanced Systems and Materials Production Washington, DC 20545

40 Chicago Bridge and Iron Company Matt Husain

800 Jorie Blvd

Oak Brook, IL 60521
No. of

Copies

ONSITE

DOE RICHLAND OPERATIONS OFFICE

ENERGY PROGRAMS DIVISION

H. E. Ransom

37 Pacific Northwest Laboratory

B. M. Johnson (30)

Technical Information (5)

Publishing Coordination $\mathrm{pg}(2)$ 